\title{
Values Education in Arabic Proverbs of Mahfudzat
}

\author{
Muthoifin ${ }^{1, *}$, Nuha $^{2}$ \\ ${ }^{1}$ Department of Islamic Education, Universitas Muhammadiyah Surakarta (UMS) Surakarta, Indonesia \\ ${ }^{2}$ Department of Islamic Education, Institut Agama Islam Negeri (IAIN) Surakarta, Indonesia
}

Received July 22, 202; Revised October 29, 2020; Accepted November 11, 2020

\section{Cite This Paper in the following Citation Styles}

(a): [1] Muthoifin, Nuha , "Values Education in Arabic Proverbs of Mahfudzat," Universal Journal of Educational Research, Vol. 8, No. 12A, pp. 7274 - 7281, 2020. DOI: 10.13189/ujer.2020.082510.

(b): Muthoifin, Nuha (2020). Values Education in Arabic Proverbs of Mahfudzat. Universal Journal of Educational Research, 8(12A), 7274 - 7281. DOI: 10.13189/ujer.2020.082510.

Copyright $\bigcirc 2020$ by authors, all rights reserved. Authors agree that this article remains permanently open access under the terms of the Creative Commons Attribution License 4.0 International License

\begin{abstract}
The purpose of this study is to find a general description of mahfudzat book, the core or content of Islamic education contained in mahfudzat and values contained in mahfudzat based on the Islamic perspective. The methods used are library research, and qualitative type, the approach used content analysis, descriptive, inductive, normative, and literature genetic structuralism approach. The general description of mahfudzat book includes several remarks of the Prophet, Companions of the Prophet, verses of wisdom, and ulama's guidance and poets. The discussion began with a general theme of advice for teachers, various Arabic proverbs, its principles, and closed with practice exercises. The core of the book discussion consists of three chapters. The first is about education, the second is about manners, the third is about social ethics. The total number of mahfudzat in this book is ninety two proverbs. While the Islamic values education contains five aspects of education, namely aqidah (creed) education, knowledge, amaliyah (deeds), morals, and social. Applications. This research can be used for universities, teachers, and students as a reference and textbook in learning. The contribution of this study resulted in finding five values education, namely aqidah (creed) education aims to nurture human beings always to strengthen faith and purify their souls. Science education, to uphold human dignity. Amaliyah (deeds) education aims to teach human beings to behave and think positively. Moral education to guide human beings to be patient and humble and social education aims to educate human beings to establish communication among others.
\end{abstract}

Keywords Wisdom Values, Education, Morals, Arabic, Mahfudzat

\section{Introduction}

The background of this research topic is that the values in Islamic education have recently come to the attention of academics to be examined and studied in various aspects. Among these are examined from the aspect of content analysis which is considered filled with conceptual values that deserve to be formulated in education. This study focuses on the mahfudzat study. It comes to our understanding that mahfudzat itself, if often read and contemplated, is full of therein secrets, whether closely related to issues of education, morals, worshipping, social, amaliyah (deeds), and so forth. [1]

Mahfudzat or Arabic proverb, one of the groups of Arabic-language subjects, is commonly taught only in Islamic-based educational institutions such as Islamic boarding schools or ma'had in which teaches about wisdom, philosophy of Arabic-language proverbs containing aphorisms which are strongly educating. [2]

The enthralling and educational Arabic proverbs are evidently to be a collection of wise expressions and advice derived from the thoughts of prominent figures with different professions, such as wise men, poets, experts in wisdom, religious leaders, Sufis, world leaders, even the Companions of the Prophet. To date, these proverbs belong to anonymous, who are the authors and compilers, or who first delivered and taught it in Islamic schools, and boarding schools are still unknown. [3]

The connection between mahfudzat with values education or character education is fascinating to study because both have a goal that culture, the noble values of the nation, can be inherited and possessed by the young generation. This expectation that makes these two concepts are related and concord so that the young generation is not 
obsolete, always relevant, significant with the demands and purpose of life according to their time. For those reasons, out the many cultures that need to be passed on to the young generation is a language with high philosophical because language is a very important means for communication, including Arabic-speaking culture, which is one of the most important languages in the world. [4]

Therefore, considering the aforementioned indicators and problems, the statement of problem this study is to look for a general description of the Arabic proverb of Mahfudzat, find the core or content of education contained in Mahfudzat and values contained in Mahfudzat based on Islamic education's perspective. Meanwhile, the objectives of research is to find the core or content of Islamic education contained in mahfudzat and to find values contained in mahfudzat based on the Islamic perspective. [5]

The theoretical significance is expected as useful means to increase the enrichment of knowledge regarding the values education therein mahfudzat, particularly the value of aqidah (creed) education, character education, amaliyah (deed) education, and social education. Also, it examines values in mahfudzat theory based on Islamic perspective. The practical significance is expected to be the material for consideration or input, specially appointed for education managers in Islamic education, conventional education, and national education to apply the models and values of educational wisdom in mahfudzat in order to create the young generation who are pious, noble, smart, physically and mentally healthy, and are able to think and act in a visionary and progressive manner. [6]

Based on the type and model, mahfudzat consists of several forms. Among them are in the form of matsal (parable) and some are in the form of hikmah (words of wisdom). Matsal or parable is words that come from Arabic people and Arabic language, whose discussion is very concise, born from phenomena or events which if spoken has a high aesthetic value and if interpreted and translated in other languages have the equivalent value of words. [7]

Whereas hikmah is the words of Arabic people who have high intellectual abilities, its language is concise and has a very deep aesthetic value. Thus, matsal and hikmah both have in common, which is a concise aspect, simple, and meaningful discussion that can bring effect to its listener or reader. While the difference in matsal lies in the resemblance of something to other things, and hikmah lies in the language which is conveyed with values and wise advice. [8]

Given the theme of the problem, Arabic proverbs in mahfudzat are very diverse themes to discuss. Such as the themes about motivation, relationship, time, knowledge, morals, social, culture, and so on. Among Arabic proverbs referred to the problem of motivational education are:

"He who walks down the right path will surely arrive".
"He who strives finds (what he seeks)".

"As you sow, so shall you reap". [9]

These expressions, if examined deeply, have very deep meaning. Concurrently, these expressions are very well-known among academics and the public, which implies that if we have the will and desire we will find the way and solution. Proverbs containing the theme of relationship and friendship in Arabic proverbs are as follows:

"Whoever has a little honesty, has also a little friend".

"Glory be with manners, (kindness) not by race".

"The best friend at all times is book".

These mahfudzat explain about the importance of honesty in one's life, especially in finding friends. Inevitably, people will not believe and befriend with liar and dishonesty. Thus, honesty is the key to finding friends and relationships so that someone can be trusted by others.

Proverbs containing the theme of time. Below are some mahfudzat that contain and discuss the importance of time, opportunity, and time management:

"Time is gold"

"Time is like a sword; if you don't cut it it'll cut you".

"Seeking knowledge at a young age is like engraving on a stone, seeking knowledge at old age is like engraving on water". [10]

These mahfudzat explain the importance of time, exhausted gold or wealth can be sought, but passing time will not be repeated though one is willing to buy it at a high price. Yet, sometimes human beings are deceived by the spare time they have until they neglect their obligations. The Prophet Muhammad also reminded his followers to make good use of time as narrated in Bukhari hadith saying "There are two blessings which many people lose: (They are) Health and free time for doing good". Therefore, time is more valuable than gold, one should use it as wisely as possible and not neglect the time one had. Proverbs containing the theme of knowledge. These are some mahfudzat that contain and discuss the importance of studying:

"Seek education from the cradle to the grave'.

"Think of the going out before you enter".

"Seek knowledge, for someone is not born smart. Smart one is not equal to fool one". [11]

Mahfudzat above explain the importance of studying. In seeking knowledge, humans are not limited to age and time, therefore, seeking knowledge while alive until one closes eyes. There are various hadiths and verses in Quran that require human beings to always seek knowledge as 
narrated by Ibn Majah that the Prophet Muhammad saying "every Muslim, men and women must seek knowledge, and practice knowledge they gain". Proverbs containing the theme of character and manners. Below are some mahfudzat that contain and discuss morals and manners including:

"The goodness of man's character is better than the gold".

"Manner can deceive bad offspring".

"Everything is when a lot becomes cheap, except the character'. [10]

The purpose of these Arabic proverbs is to show the value of manners. Since what is valuable before Allah is faith, deeds, and morals, not wealthy. The purpose of the term gold is only to represent the meaning of wealth. Because the glory of one is valued from the morals and manners, not from their wealth. Ibn Hajar in his interpretation of the Book of Good Manners defines manner as follows: "Adab (manner) is to use language and deeds in a good and exemplary manner". [10]

Some religious leaders define manner as identical to the concept of noble character. These expressions clearly view that manners and morals have a high-level position in the teachings of Islam. Even further at the role of manners and morals, it appears that it is the essence of the core objectives of the Islamic teachings.

\section{Materials and Methods}

The methods used are library research, and qualitative type due to collection data technique which was conducted through written manuscripts, mainly in the form of archives including books of opinions, theories, propositions/laws, and others related to the main problem as a primary source, either about the theme of mahfudzat or about the values of Islamic education, as well as other relevant data sources to this research problem.

The approach of this study used a content analysis approach, namely analyzing data in accordance with the content. Following these data, the researchers collected descriptive and textual data that is phenomenal. In managing these data, then the researchers used this analysis. Based on this analysis, the researchers conducted a scientific and comprehensive data analysis of the contents of mahfudzat and Islamic education. Other approaches are comparative, descriptive, and inductive, which are researches by conducting abstraction from collected data and finding general patterns of data. These approaches were performed without waiting for the completion of data collection, in other words, this analysis is also called analysis of conclusions and final results. [12]

This qualitative descriptive method also utilized literature genetic structuralism approach. The reason researchers used this approach is that the genetic structuralism approach studies literature not only on the text but also on the literature viewed from culture and sociological aspects. Thus, Islamic values education contained in mahfudzat can be used as a reflection of life as well as a basic principle for Islamic education. Besides, this research also used Arabic narratives containing Islamic cultural values. In addition, the researchers also used a normative approach, which is an approach to formulate conclusions about the circumstances and rules that apply to the object of research or the approach to the problem by explaining the opinions that exist about the object studied. [13]

The primary data source is mahfudzat book by Ibn Arif, while secondary data sources are books or journals related to mahfudzat and values education.

Data analysis technique. To facilitate the conclusion drawing of data collected, it was processed through content analysis, comparative, descriptive, and inductive. This analysis technique was administered by finding the data required, then the data were analyzed, interpreted, studied, and concluded based on the phenomena in the document. Furthermore, since this research is content and descriptive study, the steps used include: a) topic selection, b) sources collection, c) verification (historical criticism, the validity of sources), d) interpretation (analysis and synthesis), e) writing, and f) conclusion.

\section{Results and Discussion}

Overview of the Mahfudzat thematic Book. The general description of the book of mahfudzat by Ibn Arif was first published in $2018 \mathrm{M} / 1440 \mathrm{H}$ and has been printed several times as the best seller category, including al-hadith and atsar (the Prophet's companions' sayings), verses of wisdom, ulama's advice and the poets. The discussion in this book begins with the main theme of advice for teachers, in the middle of the book, it discusses various kinds of Arabic proverbs, mahfudzat, and its principles, and ends with practice exercises. The core of the discussion of mahfudzat in this book consists of three chapters. The first chapter discusses science, including the virtues of knowledge, to seek knowledge, problems of science, the virtues of knowledgeable people, and inspiring stories. The second chapter is adab (manners), including the virtue of $a d a b, a d a b$ of pupils towards teachers, $a d a b$ of pupils towards themselves, adab of pupils towards time, and adab of pupils to others. The third chapter is kinship, including kinds of people, socialization, speaking, and properly speaking. The total number of mahfudzat in the book is ninety two proverbs. [10]

Values Education contained in mahfudzat book. Nasrullah in his research concluded that education in Islam contains various values that support the implementation of education and even become a series or system within. 
These values are the basis for children's mental development so that they can provide output for education in accordance with the expectations of their community. Given so many Islamic values contained in Islamic education, the researchers analyzed by giving limitations to the most basic values in education. [14] It is based on the conclusion of Ahmad's interpretation that the core of values education is as in the Qur'an al-Asr 1-3. According to him, education in Islam has criteria that differentiate it from other general education. The education of the Quran concerning both lives explicitly contains five elements that must be applied concurrently, namely creed, knowledge, deeds, morals, and social. [15]

The values education contained in mahfudzat book according to the researchers are considering several previous information, implicitly or explicitly contain five aspects of education, namely education of creed, knowledge, deeds, morals, and social. In this discussion, the researchers analyzed and found some values education within mahfudzat book. From ninety two mahfudzat, the researchers observed ten mahfudzat which contain those five values.

Values Education. Values in the Islamic education perspective are various forms and patterns which are interrelated. It even becomes a unified whole system in Islamic education. These values are placed by education experts as the basis in developing the soul of students so they can provide tangible benefits and contributions in the wider community. Due to the many values contained in Islamic education, this research will limit some basic values that are considered important and basic, namely the relationship of the value of creed, the value of worshipping, and the value of mental and physical health. [16]

The Value of Aqidah (creed) Education (aqidah Islamiyah). Creed or faith is a trust that is bounded to one's heart with full conscience and no doubt to its doer. This attitude of belief will continue to influence the orientation of life, attitudes, and daily activities. While Al Ghazali states that faith is to speak with tongue, acknowledge the truth with heart, and practice with body. The formation of faith must be instilled in students since their childhood, in line with the growth of their personality. Values of faith must be established in children through introducing the name of God and His messengers, teaching the creator of the universe through exemplary stories, introducing the Greatness and Majesty of Allah. Strong and embedded creed (aqidah) in an individual's soul is important in the development of children's education. One that can strengthen aqidah is the children with the value of sacrifice within them to defend aqidah that is accepted to be true. The stronger the value of sacrifice, the more solid aqidah will be. [17]

The value of religious education includes aspects of education that deserve to get the first and foremost attention from parents. Providing this education with sincerity to children is fundamental parents must never leave. Faith is a pillar that underlies Islam's value in oneself. As the expression Mahfudzat; "The faith education aims to educate human beings to strengthen faith or belief and purify soul" [18]

Therefore, religious education in mahfudzat must be used as one of the main points in teaching piety to children. It is expected that in the future they will grow up to be individuals who believe in Allah, obey His commands and stay away from His prohibitions. With strong faith, one can fortify himself from committing sins and bad habits.

The Value of Worship Education. Worship is a submissive act of an individual born from the heart and acted out by the body to glorify Allah. Obedience is a servant who dedicates himself only to his Lord. Worship is proof of an individual who believes and encompasses faith. Therefore, students should be introduced in the early with the values of worship by inviting children to places of worship, showing forms of worship, introducing the meaning of worship, and teaching benefits and rewards for those who worship. [19]

The education of children in worship is considered as a complementary of aqidah education because the value of worship of children will increase their credence of teachings in Islam. The more value of worship they possess, the higher the value of their faith. As mahfudzat phrase states: "Gaining the pleasure of Allah as He commands". [20]

Accordingly, the true value of religious education should be determined as one of the points of the values in education, so that one day they will grow into human beings who are devout according to teachings in Islam.

The Value of Health Education. Health is an important aspect of human life. Health is sometimes seen as a normal matter. People will come to realize the importance of health when they or their loved ones get sick. In other words, health is confined to the subject of pain and finding the cure. Considering the importance of health for the individual, especially in the modern era, there are so many novel diseases that come to light. Thus, it is necessary for individuals to pay more attention to their children by teaching health education as a basic element in values education. Hence, Islam commends that individuals always take care of their health, for the common good. Mentally and physically healthy. [21]

Upholding Human Dignity Education. A Muslim has rights over other Muslims, though he has rights, this has been widely explained by the Prophet Muhammad in many occasions. "The parable of the believers in their affection, mercy, and compassion for each other is that of a body. When any limb aches, the whole body reacts with sleeplessness and fever". Therefore, it is very rational for every Muslim to maintain the dignity of other Muslims and help each other (in goodness) if other Muslims need help. [22]

Every human is obliged to defend his dignity, if disturbed he is obliged to defend according to respective 
abilities. Islam has safeguarded the dignity of Muslims from unfavorable words and talking behind them, regardless they are true. Thus, this act is a great mistake and sin.7 The strategic steps one can take to uphold Muslim dignity are as follows:

\section{Do not ridicule others.}

Do not self-deprecate.

Do not give an ill name to others.

Repentance Education. Repentance represents remorse or regrets for misdeeds by pledging with one's whole heart to never commit the same sins or misdeeds and return to Allah the Almighty. Repentance is the beginning of the life of someone who has established oneself to be devoted to Allah (suluk). Repentance is the root, foundation, or base for those who achieve success.

Someone who has committed sins or misdeeds has become an obligation for one to immediately return (repent) to Allah SWT so that one does not act continuously in disobedience, which will make one farther from the mercy of Allah SWT. By returning to Allah the Almighty, one is expected to become a person who is getting closer to the Creator. Repentance must be shown when a person commits major and minor sins. Minor sins committed continuously and not immediately atoned by repentance to Allah will accumulate into major sins.

Husnuzhon Education (Positive Thinking). Prejudiced is such a reprehensible character and will be eventually punished with sin, and therefore must be opposed to. Islam teaches Muslims to think positively, especially for those with noble personalities. Thus, husnuzhon (positive thinking) must be accustomed to one's life to become an excellent individual.

Prejudice is assuming that someone is committing misdeeds or having prejudice without a firm base that reinforces the suspicion. Prejudice as aforementioned hadith is as worst kind of falsehood. People who point prejudice against others denote bad regard to others regardless of baseless accusation. Prejudice will worsen the relationship with those who are being accused, though others are not necessarily as bad as one's prejudice.

Prejudice in matters of faith is indeed unlawful. Therefore, it is untrue if faith in Allah is based solely on conjecture. When examined, one of the causes of ancestors deviated from faith in Allah was their wavering faith in Allah the Almighty.

\section{Ta'aruf Education (Recognize Each Other)}

To create a harmonious society is not enough to only possess ta'aruf (recognize each other), yet must be nurtured and instilled with sincerity through efforts that can build a relationship between human beings lasts. This effort is known as silaturrahim. Silaturrahim means strengthening of kinship ties. Silaturrahim is a teaching that must always be nurtured to flourish. Additionally, silaturrahim has broad and deep value, which is not merely strengthening of ties, more than that, silaturrahim can also be used as a means to stimulate sustenance. [23]

Silaturrahim is morality in Islam that must always be encompassed because it brings many benefits. According to al-Faqih Abu Laits Samarqandi as cited by Rahmat Shafi'i, there are ten advantages of having silaturrahim:

Gaining the pleasure of Allah as He commands.

Giving joy to others.

Being adored by angels.

Bringing praise of other Muslims to oneself.

Displeasing satan.

Prolonging the age.

Adding up the fortune.

Pleasing deceased relatives, they are contented if their children and grandchildren do silaturrahim.

Cultivating affection among families to stimulate the spirit of helping when needed.

Gaining reward in Hereafter because the doer will always be remembered and prayed for one's kindness.

Egalitarian Education (Equalitarianism). One of the grandest aspects of Islamic teachings is the principle of equal rights which has been prescribed for mankind. Human beings are equal before Islam. There is no difference between black and white, yellow and red, rich and poor, king and servants, leaders, and followers. Therefore, it is unjust if arrogance emerges due to the difference in social rank and offspring. The noblest person before Allah is the most pious and has excellent deeds.

Thus, Islam in its Shari'a (law) teachings reinforces respect for human beings, guarantees their freedom of life and rights, and position before the law is equal. No teaching to aggrandize one another before the law but practicing goodness and abandoning sins and disobedience. The form of equality includes the application of the law to perpetrators of crime without discriminating against the social status of the perpetrators. [24]

It can be concluded that human beings' positions are equal that whoever commits mistakes deserves the punishment, regardless of background and position since piety only distinguishes one from the other.

Table 1. Values Education

\begin{tabular}{|c|c|}
\hline Values Education in Islam & $\begin{array}{c}\text { Values Education in } \\
\text { Mahfudzat }\end{array}$ \\
\hline $\begin{array}{c}\text { Upholding Human Dignity } \\
\text { Education }\end{array}$ & Faith Education \\
\hline $\begin{array}{c}\text { Repentance Education } \\
\text { Husnuzhon Education (Positif } \\
\text { Thinking) }\end{array}$ & Amaliyah (deeds) Education \\
\hline $\begin{array}{c}\text { Ta'aruf Education (Recognize } \\
\text { Each Other) }\end{array}$ & Akhlak (morals) Education \\
\hline $\begin{array}{c}\text { Egalitarian Education } \\
\text { (Equalitarianism) }\end{array}$ & Social Education \\
\hline
\end{tabular}

\section{Core of Education}

Currently, many Islamic education activists had revealed 
unique values contained in various Islamic literature. It emerged due to the different perspectives of its contents. Islamic education does have criteria that distinguish it from other education. Islamic education explicitly mentioned in Qur'an and Sunnah apparently contains four elements that must be applied simultaneously, namely faith, deeds, morals, and social. As the word of Allah in Surah al-Ashr verses 1-3: "By time. Indeed, mankind is in loss, Except for those who have believed and done righteous deeds and advised each other to truth and advised each other to patience". [25]

Faith education according to Muhammad Fadhil al-Jamali is the main pillar of Islamic education. The education system based on the foundation of faith will bring a better quality of physical and mental results for faith is the relationship between the servant and the Creator.

Amaliyah education is highly considered in Islam because of its great benefits for life in the world in the form of kindness and joy for individuals and society. Good deeds are related to the harmony and coexistence of human relations with God and human relationships with oneself that will form individual piety, relationships among human beings that will form social piety (social solidarity), and relationships between human and natural surroundings. The quality of this pious deed will determine the degree of piety (spiritual achievement/faith) of a person before Allah.

Scientific education starts with reading and writing skills and the development of sciences such as the development of religious and technological sciences. Among the proofs of the Qur'an that precedes modern science is water as the origin of life. This is in accordance with Surah al-Qalam verse 1: Nun. By the pen and what they inscribe.

Moral education is the soul of Islamic education because Islam has inferred that character education and morals are the souls of Islamic education. Morals or ethical education according to 'Abd al-Qâdir Ahmad is the universal message contained in the verses of Qur'an about morals (al-akhlâq) is how to possess noble character and how to restrain oneself from despicable morals by encompassing Allah's commands and prohibitions. This is in line with the prophetic mission of the Prophet Muhammad, namely to perfect the noble character. As the Prophet said: "I have been sent to perfect good character”. [21]

Social Education. Human life as social beings is faced with social problems that are inseparable in life. These social problems arise as a result of relationships with other humans and as a result of one's behavior. These social problems are different between one to another due to the differences in the level of cultural development, the nature of their population, and the state of their natural environment. Social education is an essential aspect of Islamic education because humans are, by their very nature, social creatures who must recognize the similarities and differences of every tribe, nationality, men, and women as part of society. [26]
Table 2. Mahfudzat and Values Educational

\begin{tabular}{|c|c|c|}
\hline Education & Meaning & Interpretation \\
\hline \multirow{3}{*}{ Faith } & $\begin{array}{c}\text { Sincerity is indeed } \\
\text { beautiful }\end{array}$ & \multirow{3}{*}{$\begin{array}{l}\text { The faith education } \\
\text { aims to educate } \\
\text { human beings to } \\
\text { strengthen faith or } \\
\text { belief and purify } \\
\text { soul. } \\
\end{array}$} \\
\hline & $\begin{array}{c}\text { People's satisfaction is } \\
\text { unreachable }\end{array}$ & \\
\hline & $\begin{array}{l}\text { Those who are honest, } \\
\text { will surely win }\end{array}$ & \\
\hline \multirow[t]{3}{*}{ Science } & $\begin{array}{l}\text { Seeking knowledge at a } \\
\text { young age is like } \\
\text { engraving on a stone, } \\
\text { seeking knowledge at old } \\
\text { age is like engraving on } \\
\text { water. }\end{array}$ & \multirow{3}{*}{$\begin{array}{l}\text { Science education } \\
\text { aims to uphold } \\
\text { human dignity to } \\
\text { become a noble } \\
\text { human and bring } \\
\text { benefits to others. }\end{array}$} \\
\hline & $\begin{array}{l}\text { Seek education from the } \\
\text { cradle to the grave. }\end{array}$ & \\
\hline & $\begin{array}{c}\text { Think of the going out } \\
\text { before you enter. }\end{array}$ & \\
\hline \multirow{3}{*}{ Amaliyah } & Patience helps all works. & \multirow{3}{*}{$\begin{array}{l}\text { Amaliyah education } \\
\text { aims to teach humans } \\
\text { to behave and think } \\
\text { positively so that } \\
\text { one's life becomes } \\
\text { more productive and } \\
\text { valuable in terms of } \\
\text { deeds. }\end{array}$} \\
\hline & $\begin{array}{c}\text { Try and pay attention, } \\
\text { you must be someone } \\
\text { who knows. } \\
\end{array}$ & \\
\hline & $\begin{array}{l}\text { Today's egg is better than } \\
\text { tomorrow's chicken. }\end{array}$ & \\
\hline \multirow{3}{*}{ Akhlak } & $\begin{array}{l}\text { The goodness of man's } \\
\text { character is better than } \\
\text { the gold. }\end{array}$ & \multirow{3}{*}{$\begin{array}{l}\text { Akhlak education } \\
\text { seizes to teach } \\
\text { humans to act } \\
\text { patience, iffah } \\
\text { (abstain oneself from } \\
\text { the unlawful act), } \\
\text { izzah (esteem), } \\
\text { modesty. }\end{array}$} \\
\hline & $\begin{array}{l}\text { Manner can deceive bad } \\
\text { offspring. }\end{array}$ & \\
\hline & $\begin{array}{l}\text { Everything is when a lot } \\
\text { becomes cheap, except } \\
\text { the character. }\end{array}$ & \\
\hline \multirow{3}{*}{ Social } & $\begin{array}{l}\text { Whoever is patient, will } \\
\text { win. }\end{array}$ & \multirow{3}{*}{$\begin{array}{c}\text { Social education } \\
\text { aims to educate } \\
\text { human to always tie } \\
\text { communication with } \\
\text { others because } \\
\text { opening relations to } \\
\text { others stimulate good } \\
\text { fortune. }\end{array}$} \\
\hline & $\begin{array}{c}\text { The best friend at all } \\
\text { times is book. }\end{array}$ & \\
\hline & $\begin{array}{l}\text { Glory be with manners, } \\
\text { (kindness) not by race. }\end{array}$ & \\
\hline
\end{tabular}

\section{Conclusion}

1. The results of this research is the general description of the book of mahfudzat by Ibn Arif was first published in $2018 \mathrm{M} / 1440 \mathrm{H}$ and has been printed several times as the best seller category, including al-hadith and atsar (the Prophet's companions' sayings), verses of wisdom, ulama's advice and the poets. The discussion in this book begins with the main theme of advice for teachers, in the middle of the book, it discusses various kinds of Arabic proverbs, mahfudzat, and its principles, and ends with practice exercises. The core of the discussion of mahfudzat in this book consists of three chapters. The first chapter discusses science, including the virtues of knowledge, to seek for knowledge, problems of science, the virtues of knowledgeable people, and inspiring stories. The second chapter is $a d a b$ (manners), including the virtue of $a d a b$, $a d a b$ of pupils towards teachers, adab of pupils towards 
themselves, adab of pupils towards time, and adab of pupils to others. The third chapter is kinship, including kinds of people, socialization, speaking, and properly speaking. The total number of mahfudzat in the book is ninety two.

2. The findings in this study are values education in the book of mahfudzat are meaningfully or explicitly contain five aspects of education, namely education of faith, science, deeds, morals, and social. a. The value of religious education aims to educate humans to always strengthen faith and purify the soul; b. The value of scientific education aims to uphold human dignity, be a noble human being, and bring benefits to others; c. Amaliyah education aims to educate human beings to always behave and think positively so that life becomes more productive and valuable in terms of deeds; d. Value of moral education aims to educate human beings to be patient, iffah, izzah, humble, and; e. The value of social education aims to educate human to always tie communication with others because opening relations to others stimulate good fortune. These five elements must exist and go concurrently, dynamically, wholly, inseparable, and complementary. Because based on the perspective of Islamic teachings, these values education have unique and distinctive criteria that are decorated with philosophical meaning, wisdom, and guidelines for one's life to be safe now and hereafter.

\section{Acknowledgements}

The authors would like to thank the rector UMS (Universitas Muhammadiyah Surakarta) and the chairman and staff of the LPPI (Lembaga Pengembangan Publikasi Ilmiah) UMS for supporting the publication of this article.

\section{REFERENCES}

[1] H. P. Daulay, "ISLAMIC EDUCATION IN INDONESIA : A Historical Analysis of Development and Dynamics," 4th Int. Conf. Community Dev. ASEAN ®2017, vol. 13, no. 2, pp. 291-307, 2017, [Online]. Available: http://mpsi.umm.ac.id/ files/file/291_ ISLAMIC EDUCATION IN INDONESIA A Historical Analysis.pdf.

[2] E. Kusnadi, K. Sobur, and A. Aziz, "in Between Islamic Boarding School: a Study of Al-Mubarok Al-Islam Within the Social Changes of Seberang Kota Jambi,” Addin, vol. 11, no. 1, p. 101, 2017, doi: 10.21043/addin.v11i1.1920.

[3] S. Shobron and A. Anshori, "Method for Developing Soft Skills Education for Students,” Univers. J. Educ. Res., vol. 8, no. 7, pp. 3155-3159, 2020, doi: 10.13189/ujer.2020.08074 4.

[4] S. R. Fauzi, "The Effect Of The Mahfudzhat Subject Toward The Student's Arabic Vocabulary Mastery, (Quasi Experimental Study In Class VIII Ummul Quro Cihampelas West Bandung 2012/2013 School Year),” pp. 2012-2014,
2013.

[5] H. Fauziyah, "APPLICATION OF MAHFUDZAT METHOD: FIELD RESEARCH, TEST RESULTS OF TEACHING LEARNING PROCESS AT MAN MODEL BOJONEGORO,” Didakt. Relig., vol. 5, no. 1, pp. 91-118, 2017.

[6] Hermawan, "PENGARUH PEMBELAJARAN MAHFUDZHAT TERHADAP AKHLAK SANTRI PONDOK PESANTREN IBADURRAHMAN CIPONDOH TANGERANG,” UIN Syarif Hidayatullah Jakarta, 2018.

[7] M. I. Fasa, "Gontor As the Learning Contemporary Islamic," Semant. Sch., vol. 14, no. 1, pp. 141-174, 2017, [Online]. Available:

https://pdfs.semanticscholar.org/024d/b6106f4a99433f5620 ca61c82c3d73bec0df.pdf.

[8] N. Muthoifin, "Al-Shulhu wa Shira': Mahfudzat," in International Conference On Linguistics (ICLing), 2018, pp. $1-4$.

[9] F. S. Matin, Mahfudzat 3 pdf.pdf, 8th ed. Solo, 2018.

[10] I. Arief, Mahfudzat Tematik Bunga Rampai Peribahasa Arab "Ilmu dan Adab." Kendal Jawatengah: QS Qolbun Salim, 2018.

[11] U. Husen, "INTEGRASI BAHASA ARAB KE DALAM ILMU-ILMU KEISLAMAN PADA PRODI PENDIDIKAN AGAMA ISLAM (PAI) FTK UIN AR-RANIRY Oleh:,' , لساننا مجلة دورية علمبة في اللغة العربية وتعليهها , vol. 05, no. 01, pp. 87-104, 2016.

[12] C. Williams, “Research Methods,” J. Bus. Econ. Res., vol. 5, no. 3, pp. 65-72, 2007.

[13] Muthoifin, "Shariah Hotel and Mission Religion in Surakarta Indonesia,” Humanit. Soc. Sci. Rev., vol. 7, no. 4, pp. 973-979, 2019, doi: 10.18510/hssr.2019.74133.

[14] Muthoifin, Nuha, and S. Shobron, "Education and Leadership in Indonesia: A Trilogy Concept in Islamic Perspective,” Univers. J. Educ. Res., vol. 8, no. 9, pp. 42824286, 2020, doi: 10.13189/ujer.2020.080954.

[15] H. Y. M. Nasrullah, "Nilai-Nilai Pembelajaran Bahasa Arab Dalam Pendidikan Islam,” J. Pendidik. Univ. Garut, vol. 09, no. 01, pp. 91-102, 2015.

[16] R. A. R. Muthoifin, Nur Hanif Wachidah, "Contribution of Kartini's Thought on Women Education,” Humanit. Soc. Sci. Rev., vol. 8, no. 2, pp. 143-150, 2020.

[17] A. Z. Mubarok, "Model pendekatan pendidikan karakter di pesantren terpadu," Ta'dibuna J. Pendidik. Islam, vol. 8, no. 1, p. 134, 2019, doi: 10.32832/tadibuna.v8i1.1680.

[18] J. F. A. Rohas, “تطوير نموذج الكتاب المدرسي. القائم على المعنى

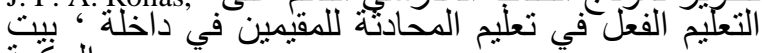
الحكمة,", IAIN Surakarta, 2019.

[19] J. Francoise, "Pesantren as the Source of Peace Education," Walisongo J. Penelit. Sos. Keagamaan, vol. 25, no. 1, p. 41, 2017, doi: 10.21580/ws.25.1.1161.

[20] Andi Fajar Awaluddin, "Implementasi nilai-nilai dakwah santri melalui peribahasa arab mahfudzat (Tinjauan Sosiolinguistik, Studi Atas Buku Al-Mahfudzat Kelas IX 
MTs Pondok Pesantren Modern Al-Junaidiyah Biru Bone Karya KM. Syarifuddin Husain)," Al-Din J. Dakwah dan Sos. Keagamaan, vol. 05, no. 01, pp. 1-13, 2019.

[21] N. Hidayat, “The Implementation of Character Education Model at Islamic Boarding School of Pabelan, Magelang, Central Java,” J. Pendidik. Islam, vol. 5, no. 2, p. 431, 2016, doi: 10.14421/jpi.2016.52.431-455.

[22] S. Shobron and S. A. Rahman, "Humanist islam in indonesia ahmad syafii maarif perspective," Humanit. Soc. Sci. Rev., vol. 7, no. 6, pp. 780-786, 2019, [Online]. Available: https://giapjournals.com/index.php/hssr/article/view/hssr.20 $19.76118 / 2384$.
[23] S. R. Fauzi, “ تأثثر مادة در اسة المحفوظات علي إستيعاب

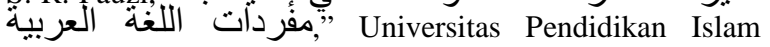
Bandung, 2013.

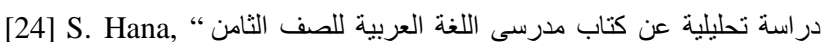

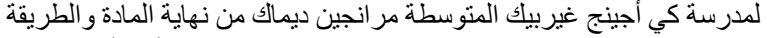

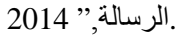

[25] A. Mustaffa, “Teaching Methodologies In Islamic Education In 21 st Century; Challenges And Perspective," no. March, 2019.

[26] E. C. Syamsul Hidayat, Sudarno Shobron, "Pancasila and Communism Perspectives on Islamic Thought,” Int. J. Psicososial Rehabil., vol. 24, no. 8, pp. 3500-3508, 2020. 